\title{
Development of Retail Chains on the Russian and International Markets in the Context of Globalization
}

\author{
Julya Valeeva ${ }^{1}$, Irina Akhmetova ${ }^{1}$, Natalya Sharafutdinova ${ }^{2}$ \\ ${ }^{1}$ Kazan State Power Engineering University, Kazan 420066, Russian Federation \\ ${ }^{2}$ Kazan Federal University, Kazan, 420008, Russian Federation \\ *Corresponding author. Email: valis2000@mail.ru
}

\begin{abstract}
The main purpose of this study is to consider the features of the development of retail chains services on the world and Russian markets, taking into account the factors of globalization. The article considers the economic essence of international trade networks in the context of globalization, the stages of their formation and development in the world economy, the competitive advantages of international trade networks and factors of their international development.

The transformation of the theory from the classical economy to the cooperative network and information economy through scientific works and the development of a model is presented.

Investigating internal factors of service development, it should be noted that for enterprises of network formats, which include retail chains, it is very important to have their own standards of service, personalized approaches to interaction and contact with consumers to ensure the quality of trade services.

This article is based on a comparative and economic analysis of the study of trends in the development of retail chains. On the basis of correlation and regression analysis and the system of indicators selected by the authors, the efficiency indicators of network formats are calculated. SWOT analysis allowed us to identify threats and opportunities for the development of international retail chains in the Russian market. The past analysis summarizes the external factors of retail chain development.

Based on the factual development of retail trade networks and analysis of literary sources, the main stages of their development in the world economy are determined. The authors identified the features of the development of retail trade networks. The essential model of cooperative network organizations is defined.
\end{abstract}

Keywords: Globalization, international and domestic distribution network, development of the world market, network organization.

\section{INTRODUCTION}

The process of globalization has a strong impact on the development of retail trade. Thence, in the 2000s, the focus of retail chains was on the countries of Eastern Europe, which during this period joined the European Union [1]. Currently, it is Asia that is becoming the most attractive for the development of e-Commerce and mobile Commerce (m-commerce), and in Western Europe and the United States, its growth rates are already beginning to decline. Therefore, if 2-3 years ago they were $20-30 \%$, today they are about $10 \%$ a year [2].

Modern trends, problems, the history of retail development, investment attractiveness of the industry are considered in many works [3-6]. An important contribution to the implementation of the tasks of this study was the work of foreign researchers devoted to the analysis of promising areas of retail development.

The purpose of the work is to identify the directions of their further development and develop practical recommendations for improving the efficiency and profitability of their activities based on the study of the world experience of the largest international trade networks. In order to achieve this goal, the following main tasks were set and solved: i) determining the economic essence of international trade networks, studying the stages of their formation and the features of the development of various formats; ii) considering the competitive advantages of international trade networks and the main factors of their development; iii) conducting a comparative analysis of the effectiveness of international and Russian trade networks.

The object of research is international trade networks at the present stage in the world and Russian economies. The subject of the research is the processes of formation and development of international trade networks, their positions on the world and Russian markets, as well as strategic directions for their further development. The paper highlights the competitive advantages of international retail chains, such as the availability of world experience, financial resources, an established procurement system, brand awareness, centralized purchases at the most favorable prices. The factors contributing to the development of international trade networks in foreign markets, including issues of state regulation of their activities, as well as the problems they face, are studied. 


\section{MATERIALS AND METHODS}

Modern analysis of the processes of the Russian and world economy has allowed us to establish that the economy of production is being replaced by the economy of the service sector. At the same time, the traditional aspect is to consider services as the third sector of the economy, which occupies 2/3 of the global GDP structure.

The service sector dominates in the developed economies of the United States, Germany, and France. Services account for $75 \%$ of the United States GDP. The study of retail trade as the largest sector of the service sector is relevant in view of qualitatively new interactions, integrations, cooperation of resources of trade enterprises and stakeholders, the formation of an information marketing field that can increase market stability and ensure the achievement of competitive advantages for all participants in the processes [7].

The study of cooperative-network interactions and competencies first appeared in the second half of the $20^{\text {th }}$ century, which were due to the saturation of markets, the ability of large companies to produce products in demand by consumers, taking into account the personalized behavior of consumers. Insufficient description in existing theories of building economic relations, information and communication field of interaction of companies in the context of globalization and digitalization predetermined the development of new concepts.

With regard to the above, Forester [8] showed new trends in the internal organization of major companies as profit centers in interaction with independent business structures. Miles and Snow [9] showed the evolution of intra-company management structures through the transformation of linear structures into functional, divisional and matrix structures based on project type and network formations. Subsequent research has shown the impact of scientific and technological progress on productivity growth and changes in the cost structure. The change of economic forms with the transition from a free economy to a connected one.

The scientific controversy of modern research shows the disagreement that the real economy is not completely subject to classical laws, since it is inherent in cooperativenetwork principles. Thus, Viber [10] proved that in classical Economics the main role is determined by the law of decreasing marginal profitability, while the network economy is based on the law of increasing marginal profitability. It is important to note that the law of decreasing marginal returns is based on the growth of one of the factors of production at the initial stage and determines the growth of output or total product with constant technology.

Production theory, cost theory, and budget theory show that the initial investment can be provided by the growth of the aggregate product, but at subsequent stages, the growth of investment can be accompanied by the growth of the aggregate product, followed by a slowdown and their decline. Arthur [11] explained the arguments of the information economy, showing that an increase in the return on additional resources can occur due to changes in the cost structure, as well as the effects of learning. Precisely, cooperative-network relations with information and technological innovations and communications allow us to form direct network connections and feedback. This is the law of increasing marginal returns, in which the initial phase is associated with the accumulation of opportunities and growth in the network, enabling new members of the cooperation network of the Alliance at a later stage to overcome the threshold of profitability with the onset of further system growth results with little additional costs. Thus, the cooperative-network economy is exposed to factors that reduce and destroy the traditional picture of the cost-benefit ratio. In modern conditions, it is not the enterprises themselves that are competing, but cooperative and network entities. since network structures combine all the resources of the network participants ' efforts, aiming to minimize fixed production costs by effectively using joint resources and ensuring prompt and personalized sales of products and services. Moreover, it can be shown that achieving the results of effective organization of participants ' activities within the network can be carried out at the expense of quasi-permanent costs, that is, by reducing fixed costs per unit of products and services. The economic mechanism of network entities is based on a low level of quasi-permanent costs and obtaining socio-economic effects from interaction. Digitalization of business processes accelerates the process of transformation of the industrial economy to a cooperative network.

By network, we mean independent or integrated business structures that coordinate their actions for mutual benefit and benefit. We define the basic resources that ensure the growth of network effects:

- The qualifications of all employees working in enterprises network structure;

- The information field within the network as a network information within a particular network;

- Management of enterprises inside the network and the creation of shared values that shapes every member within the network;

- Coordinated activities of network participants on the strategic aspect of production and sale of products and services;

- Influence of society through social networks, mass media, professional public unions;

- $\quad$ Creating feedback with positive effects; 
- The effect of the brand in the network and customer loyalty to the strong participants of the network as a whole and its businesses;

- Knowledge and skills of all levels of management and labor process of the enterprise in the network.

These resources clarify the basic principles of network formation, what changes follow and accompany this process, but do not answer the main question - what do network partners exchange in order to achieve joint goals and final results? The primary analysis of interaction processes in the network business conducted by the authors shows that to a large extent they are achieved by exchanging various types of services between network participants:

A) Analysis of the development of RTS services in dynamics using the methodology
The definition of the integral indicator allows to define an overall strategy, and analysis at criteria and indicators methods to identify problem areas and growth points for the development of services studied networks.

B) Interaction with participants in the value chain to jointly increase value development

Retail chains in modern conditions impose strict requirements on suppliers and manufacturers, so to establish effective interaction, partners must have the following competencies.

\section{RESULTS AND IMPLICATIONS}

In the history of the development of retail chains, there are several main stages, which are shown in Table 1.

Table 1 Stages of development of retail chains in the world

\begin{tabular}{|c|c|}
\hline Period & Event \\
\hline $1859-1900$ years & $\begin{array}{l}\text { Origin of the first RTS and their initial development (first the retail chain is considered to have } \\
\text { opened the first stores in New York, an American A\&P importer Indian tea, now Great Atlantic } \\
\text { \& Pacific Tea Company). }\end{array}$ \\
\hline 1900-1930's & $\begin{array}{l}\text { A period of rapid growth. The idea of retail chains got its way spread among retailers; hundreds } \\
\text { have emerged new retail chains. American steel companies } \\
\text { open branches abroad. In the field of online trading the processes of concentration, mergers and } \\
\text { acquisitions begin. }\end{array}$ \\
\hline Since 30 years & $\begin{array}{l}\text { Period of stable growth of the RTS sphere, increase in the share of } \\
\text { retail chain market. }\end{array}$ \\
\hline Since the $50 \mathrm{~s}$ & $\begin{array}{l}\text { Active development of online trade formats in Western Europe } \\
\text { Europe. }\end{array}$ \\
\hline Since the $60 \mathrm{~s}$ & $\begin{array}{c}\text { Retail chains are beginning to apply new information technologies and actively introduce } \\
\text { innovations. }\end{array}$ \\
\hline Since the $70 \mathrm{~s}$ & Activation of globalization processes in retail trade. \\
\hline Since 2000 & $\begin{array}{c}\text { Expansion of regional representation in different countries. Development of trade services in } \\
\text { Russia and Asia }\end{array}$ \\
\hline Since 2015 & $\begin{array}{c}\text { Digitalization of retail services, application of big data in the personalization and customer- } \\
\text { oriented activities of retail chains }\end{array}$ \\
\hline
\end{tabular}

Global retail has almost a century-long history of its development, during which retail chains have gained momentum, improving their trade. In Russia, retail chains began to form much later, the reason for this could be the post-war economic situation and major changes in the political sphere of the country.

At the current stage of international trade development, the concept of involving multiple companies in global value chains (GCS) is important. The essence of the concept is that several countries participate in the production of the product, ultimately reducing the cost of production, increasing its quality through specialization in the production of individual components [12].

Network trade is characterized by a certain assortment, size of retail space, modern store formats, methods and forms. New types of stores, modern shopping centers and huge malls are being developed. Retail chain trade organizations have modern premises and are equipped with the latest technologies for conducting trade business. All this cannot but affect the competition, which is beginning to increase and is not only in the price range.

Thus, the information network model of organization of services of retail trade networks is based on the following principles:

1. The cooperative network structure consists of the cooperation of network organizations created on the basis of key processes. Network entities cooperate internally and are self-organizing units within a large cooperative network Association, but at the same time it coordinates activities with other networks.

2. An Important principle of making tactical and managerial decisions in this model is to get not the best, but fast working decisions that can be implemented 
tomorrow, while having the opportunity to make them at the next meeting or communication based on the results already obtained.

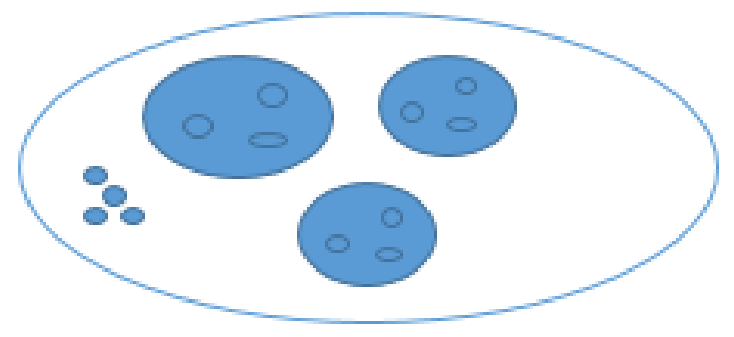

Figure 1 Model of cooperative network entities

The effectiveness of this model is due to the fact that in the existing various structures, stores are essentially represented by a team that acts relatively autonomously. all you need to do is to organize a campaign and use the potential of store employees who are often underestimated.

\section{DISCUSSION OF RESULTS}

We will analyze the competitive advantages of international retail chains and factors of their international development based on the "Porter's 5 competitive forces" model, as well as identify the key factors of competitiveness of these organizations.

Market analysis and network positioning. Every year, international retail chains increase their presence in the Russian food retail market. From 2009 to 2018, the company's share in the retail market increased from $4.4 \%$ to $188 \%$ [13].

Competitive advantages of large retail chains can be summarized as follows: i) ability to purchase large quantities of goods and get the most favorable terms from the supplier; and ii) in accordance with consumer preferences, it is possible to change the range of products and create an attractive assortment at competitive prices;
- Centralization and a high level of management of all commercial activities through the involvement of qualified specialists allow you to avoid many of the disadvantages that are typical for an individual store;

- Reducing costs per unit of product by saving on sales promotion costs, purchasing advertising that is profitable for your stores;

- Chains give their stores a certain freedom so that they can successfully compete with local consumer preferences.

The characteristics of the consumer. Some research results show that the main criteria for the attractiveness of the place where consumers buy goods were the proximity of the location relative to the house, a wide range, the quality of goods and the presence of a cooking department. It is for this reason that the number of stores of the new type "at home" is expanding, as well as supermarkets, since hypermarkets are in use, due to the obvious distance and time-consuming.

Territorial aspect of the firm's analysis. For 2019, international retail chains were represented by networks of various formats in seven of the eight Federal districts of Russia, with the exception of the Siberian district, while there was a gradual expansion in the Eastern direction (data for 2019).

Analysis of the company's performance, competitive advantages and prospects. Due to the fact that X5 Retail Group does not independently produce products, but only participates in retail resale, the cost of production is not included in the financial statements. The company's position regarding the refusal to develop the sector of production of its own products is expressed in the focus on strategic partnership with suppliers who guarantee the high quality of products supplied.

Table 2 Matrix of SWOT analysis for international retail chains

\begin{tabular}{|c|c|}
\hline Strengths & Weaknesses \\
\hline $\begin{array}{l}\text { 1. High reputation of the company's stores, established } \\
\text { image. } \\
\text { 2. Recognizable brands. } \\
\text { 3. Representation of brands and stores abroad (CIS). } \\
\text { 4 Convenient location of stores: } \\
\text { (home stores, supermarkets, hypermarkets, discounters). } \\
\text { 5. Successful advertising and effective management of the } \\
\text { company. }\end{array}$ & $\begin{array}{l}\text { 1. Poor infrastructure development in remote regions } \\
\text { (Siberia, } \\
\text { far East). } \\
\text { 2. Cases of neglect of product quality control, which is } \\
\text { the reason for the sale of expired products in stores. } \\
\text { 3. The use of reverse franchising, which complicates the } \\
\text { distribution of stores of franchisees in other regions. }\end{array}$ \\
\hline Opportunities & Threats \\
\hline $\begin{array}{l}\text { 1. Convenience of expansion to the East of Russia, as the } \\
\text { retail market } \\
\text { sales by chain stores are not mastered there. } \\
\text { 2. Increasing the range and products. }\end{array}$ & $\begin{array}{l}\text { 1. Inflation or economic instability, which will negatively } \\
\text { affect the income of the population. } \\
\text { 2. Barriers to entry into international markets. } \\
\text { 3. Risks of violations. }\end{array}$ \\
\hline
\end{tabular}




\author{
3. Emergence of brands that are not yet used by \\ "Pyaterochka" networks, "Intersection", "Carousel". \\ 4. Increase sales through the online store. \\ 5 . Increasing the number of suppliers. \\ 6. The income growth.
}

In the European Union, retail chains control 70-75\% of retail turnover (all other retail outlets: small stores, pavilions,

In kiosks, etc. occupy no more than $4 \%$ of the market). In Russia, networks occupy only 20-30\% (in Moscow $45 \%$ ). in European countries, the following retail chains have a significant result: in France - "Carrefour", "Casino Group" and "Auchan"; in Germany - "Metro cash and carry" and "Rewe"; in the UK - "Tesco", which is shown in Figure 2.

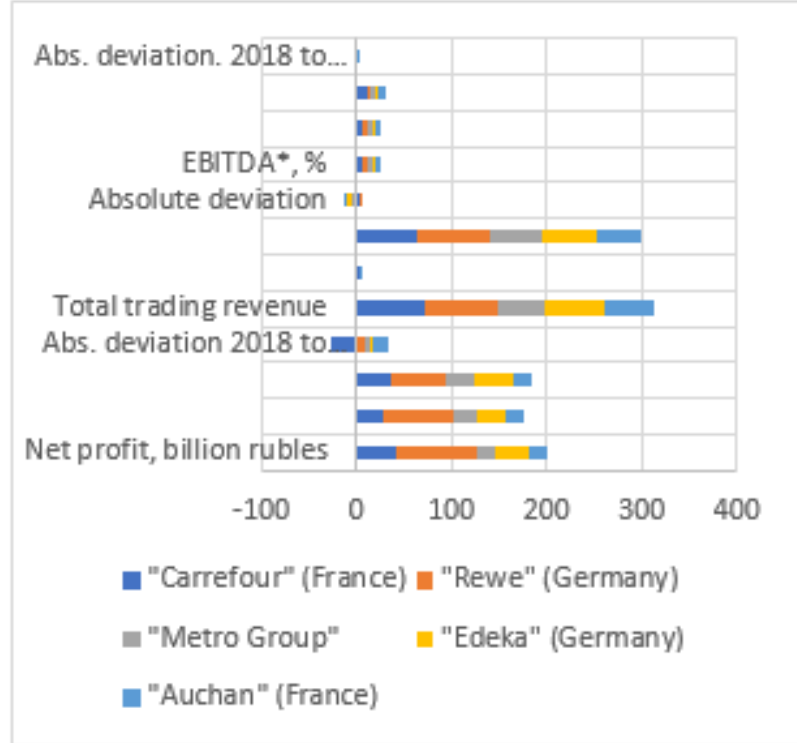

Figure 2 Dynamics of trade net profit and revenue, profitability of leading European retail chains for 2016-2018, billion rubles euro [14]

* EBITDA - (Earnings before interest, taxes, depreciation and amortization)

For a clear representation of the effectiveness of international trade networks, we will analyze the largest grocery chains by their net profit, that is, the part of the company's balance sheet profit that remains at its disposal after taxes, fees, deductions and other mandatory payments to the budget (Figure 2).

Analyzing the net profit of international retail chains abroad, we can say that the largest indicators in 2018 belong to "Carrefour" 58.1 billion rubles. Over the past three years, this retail chain has shown a negative trend. This leads to the conclusion that foreign retail chains conduct more efficient trading business than Russian chains.
4. Fluctuations in exchange rates, which will lead to changes in the company's indicators.

5. Aggressive growth and expansion of other well-known networks

6. High competition with local retail stores in the regions.

In addition to net profit, an important performance indicator is the organization's net profit margin. It provides significant and important information about financial performance. Profitability is a relative indicator that reflects the degree of profitability of the enterprise.

Technological solutions at the level of retail chains are also accompanied by an increase in the level of service for the consumer, which is reflected in the growth of inventory, which increased from 104 billion rubles in 2010 to 580 billion rubles in 2018. (the growth rate is 5.6 times, compared to 2017-119.1\%). At the same time, the inventory of retail chains in days of trade also increased from 29 days to 33 days; the maximum value was noted in 2016 - 34 days (Figure 3 ). other things being equal, we consider this trend positive for consumers, although the profitability of the network for the owner will decrease.

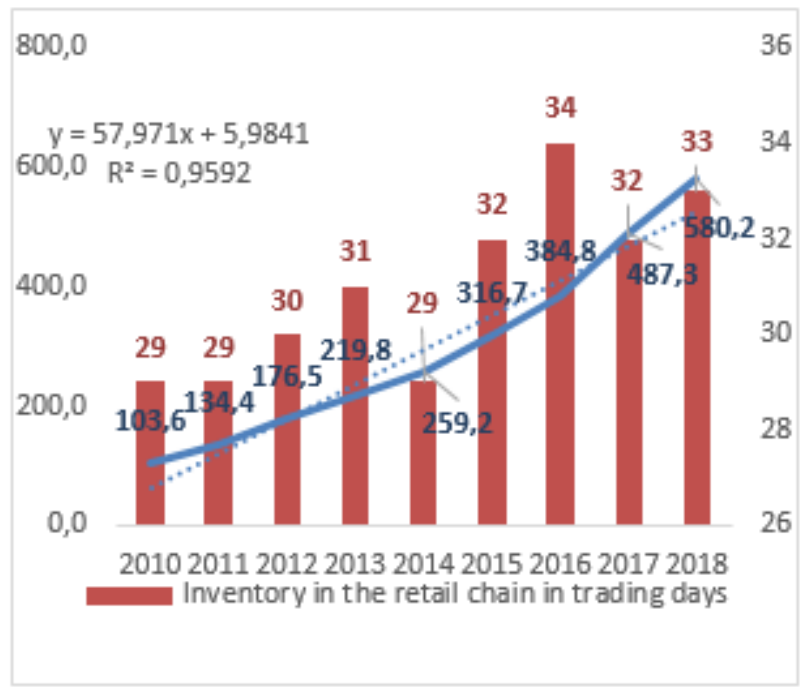

Figure 3 Dynamics of inventory in retail chains (summary according to Rosstat data (2021) [15])

The study of the practice of using digital technologies for providing services also shows a positive practice: the number of Online sales in retail chains increases rapidly every year. Total Online sales increased from 188 million rubles in 2010 to 1115 million rubles in 2018 (growth rate -5.9 times relative to $2017-118 \%$ ). The share of Internet sales in the total turnover of retail chains increased from $0.7 \%$ in 2014 to $1.7 \%$ in 2018 . when analyzing the level of technological efficiency of retail chains ' services, it is indicative to assess the profitability of personnel and investment (Figure 4). 


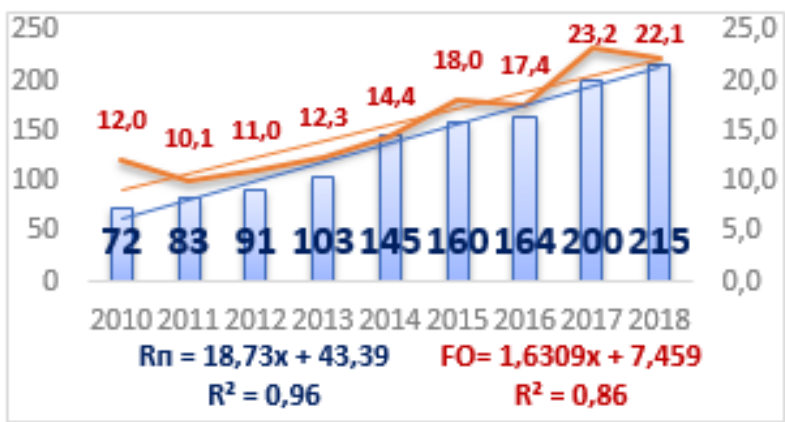

Figure 4 Performance Indicators of fixed assets and staff of retail chains (calculated by the authors)

The starting point of the scientific research carried out was the content of Art. 5 of the Federal Law of the Russian Federation of July 27, 2006 No. 149-FZ (as amended on June 8, 2020) "On Information, Informatization and Protection of Information", which states that the named phenomenon can be the object of public, civil and legal relationship. At the same time, the authors took into account; certain requirements of the Tax Code of the Russian Federation, the Civil Code of the Russian Federation and other laws. In the final part of the article, conclusions are formulated related to the need for a more in-depth use of IT in various social processes.

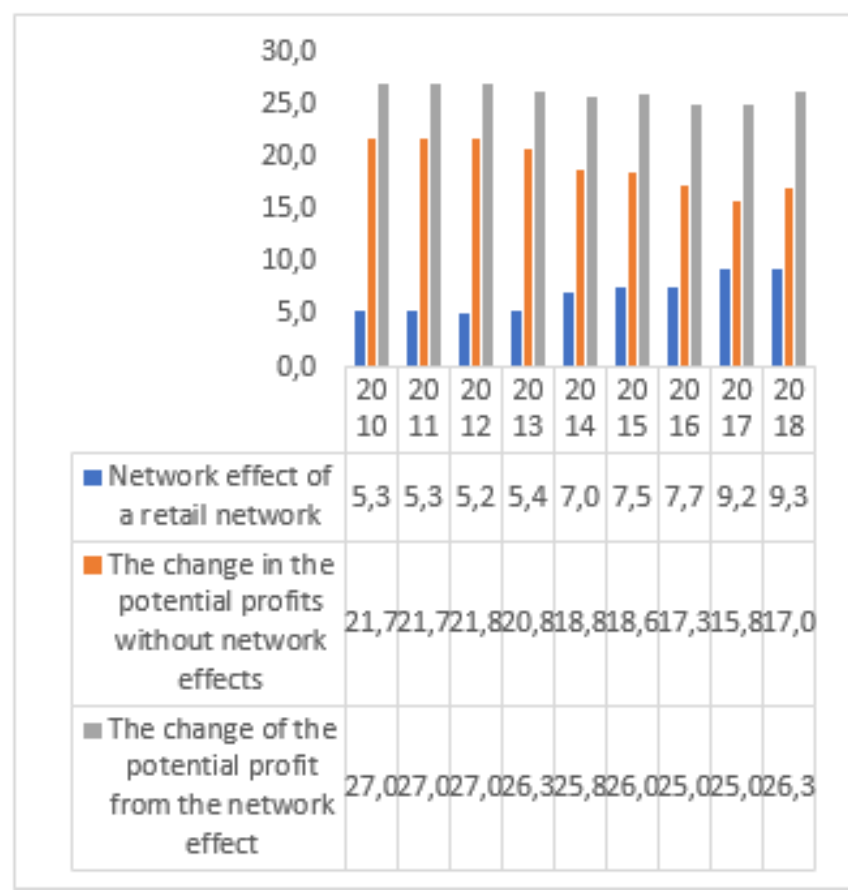

Figure 5 Change in the rate of profit growth of retail chains due to the synergetic network effect (as a percentage)

The return on capital of newly introduced fixed assets was also characterized by an increase - from 72 rubles per ruble of invested funds to 215 rubles per ruble of invested funds. For both performance indicators of retail chains, there is a positive trend with regression elasticity coefficients of 18.734 and 1.6309 , respectively.

Thus, the network effect, which is the ability to create additional value through the provision of services by retail chains of a wider list of them, flexibility, while saving on the cost of sharing assets within the network, allows you to have a higher profit compared to non-network structures. The synergetic network effect that characterizes the activity of retail chains provides an increase in additional profit and, accordingly, the profitability of goods sold, which proves their advantages relative to nonnetwork forms in retail trade.

\section{CONCLUSIONS}

Overall, the development of retail networks, as well as the assessment of their effectiveness, allow us to solve complex issues of improving the quality and profitability of the service sector. Typology of business processes and patterns in the process of providing services to retail sales networks and the use of the scorecard effect, cost and effectiveness associated with the services proposed in the framework of the developed methodology to identify and control promising aspects and factors of economic development of retail trade networks.

Our study allows to conclude that methodological issues of management of services of retail trade networks have important socio-economic value the prospects of further development of the topic consists in the development strategy services to retailers subject to the proposed methodology of assessment of efficiency of their provision and specific projects to improve the efficiency of the services sector; improvement of methodology of estimation of efficiency of retail trade networks in the context of digitization of the economy

\section{REFERENCES}

[1] G. Śmigielska, R. Oczkowska, Retailers' competitiveness on global markets. International Entrepreneurship Review 3(1) (2017), 175-196. DOI: https://doi.org/10.15678/PM.2017.0301.10

[2] M. Ingaldi, R. Ulewicz, How to make e-commerce more successful by use of Kano's model to assess customer satisfaction in terms of sustainable development. Sustainability 11(18) (2019), 4830. DOI: https://doi.org/10.3390/su11184830

[3] Yu.S. Valeeva, A. M. Naida, N. K. Potapova, E. Yu. Elesin, Mechanism of Management of Retail Networks Services, in: Proceedings of the $1^{\text {st }}$ International Volga Conference on Economics, Humanities and Sports 
(FICEHS 2019), Kazan, Atlantis Press, 2019, pp. 72-76. DOI: https://doi.org/10.2991/aebmr.k.200114.016

[4] Yu.S. Valeeva, Yu. Veber, G. Ostapenko, Client Orientation of Consumers as a Factor of Value-Based Development of Retail Chains Services, in: Proceedings of the International scientific conference "New silk road: business cooperation and prospective of economic development (NSRBCPED-2019), Prague-Saint Petersburg, Atlantis press, 2020, pp. 864-870. DOI: https://doi.org/10.2991/aebmr.k.200324.159

[5] I. Čábelková, B. Pogorilyak, W. Strielkowski, V. Stríiteský, R. Tahal, Customer store loyalty determinants: A case of the Czech Republic, DLSU Business \& Economics Review 25(1) (2015), 28-44.

[6] O. Kozlova, E. Sukhostav, N. Anashkina, O. Tkachenko, E. Shatskaya, Consumer model transformation in the digital economy era, Advances in Intelligent Systems and Computing 726 (2017) 279-287. DOI: https://doi.org/10.1007/978-3-319-90835-9_33

[7] R. Brodie, H. Löbler, J. Fehrer, Evolution of servicedominant logic: Towards a paradigm and metatheory of the market and value cocreation? Industrial Marketing $\begin{array}{llll}\text { Management } & 79 & \text { (2019), 3-12. DOI: }\end{array}$ https://doi.org/10.1016/j.indmarman.2019.03.003

[8] J. Forrester, A new corporate design, IMR: Industrial Management Review 7(1) (1965) 5-6. DOI: https://doi.org/10.1162/152417300570041

[9] R. Miles, C. Snow, Causes of failure in network organizations, California Management Review 34(4) (1992) 53-72. DOI: https://doi.org/10.2307/41166703

[10] R. Viber, Empirical laws of the network economy, Problems of management theory and practice 2 (2003) 6772.

[11] W. Arthur, Positive feedbacks in the economy, Scientific American 262 (2) 92-99. DOI: https://doi.org/10.1038/scientificamerican0290-92

[12] G. Menet, M. Szarucki, Impact of Value Co-Creation on International Customer Satisfaction in the Airsoft Industry: Does Country of Origin Matter? Journal of Risk and Financial Management 13(10) (2020), 223. DOI: https://doi.org/10.3390/jrfm13100223

[13] E. Gregova, V. Dengov, I. Tulyakova, Global Trends in Russian Retail: a Comparison of the Market of St. Petersburg and Moscow. Globalization and its socioeconomic consequences, 10(2018), 1079. https://pure.spbu.ru/ws/portalfiles/portal/38649327/iii_pa rt_final.pdf Accessed on 22 Feb 2021
[14] UNCTAD Handbook of Statistics (2015) http://unctad.org/en/PublicationsLibrary/tdstat40_en.pdf Accessed 20 Dec 2020

[15] Rosstat, Trade and services markets, https://www.gks.ru/region Accessed on 23 Feb 2021 